\title{
Customer's Behavior and Willingness to Pay for the Antioxidant Eggs
}

\author{
Rahayu Relawati ${ }^{1 *}$, Bambang Yudi Ariadi ${ }^{2}$, Harpowo $^{3}$ \\ 1,2,3 Agribusiness Department, Faculty of Agriculture and Animal Science, University of Muhammadiyah Malang Jalan Raya \\ Tlogomas 246 Malang, East Java Province, Indonesia \\ rahayurelawati@umm.ac.id
}

\begin{abstract}
Chicken eggs enriched with antioxidants are produced to provide functional foods that are healthier to consume, with a premium price. The study was intended to analyze customers' assessment, buying behavior, and willingness to pay the antioxidant (AO) chicken eggs. The study was conducted in Malang Regency, the closest location to the UMM Farm Business Unit. Primary data were obtained from interviews with customers of the AO and conventional eggs. The data were analyzed with a quantitative descriptive design and the t-test. The results suggested that customers assessed the AO chicken eggs had better nutritional content than the conventional one and produced a better impact on health. Customers' behavior indicated that the purchase of the AO eggs was still lower than conventional eggs, although customers' tasting attitude on the AO egg portrayed a higher preference. Customers were willing to pay more expensive to the AO eggs. The price of AO eggs without any label was $7 \%$ higher than the conventional counterpart during the time of the study. If the AO eggs are labeled, they will take a premium price of $21 \%$ more than conventional eggs. The results recommended the producers to do packaging and labeling to the AO eggs to expand the market. Moreover, the UMM Farm needs to consider various packaging designs based on consumer preferences and determine the market penetration of the AO eggs.
\end{abstract}

Keywords

Antioxidant, chicken egg, customers' behavior, Willingness to Pay (WTP)

Article Received: 10 August 2020, Revised: 25 October 2020, Accepted: 18 November 2020

\section{Introduction}

Chicken eggs are the most widely consumed food ingredient as a source of animal protein [1], so that the increase in population significantly increased its demand [2]. The egg consumption in Indonesia is also higher than other livestock products [3], [4]. Along with the increasing concern of food health, livestock farming has produced chicken eggs with various enrichments such as an organic substance [5], and the combination of feed and tomato flour [6] and mulberry leaves [7], as well as antioxidant addition for eggs' farming [8]. Chicken eggs that contain antioxidants have been developed by University of Muhammadiyah Malang (UMM), and marketed by the UMM Farm Business Unit. Therefore it is deemed crucial to know the consumers' assessment and their buying behavior.

Based on several previous studies, consumers who have certain health conditions show a more enthusiastic attitude towards organic food including chicken egg [9], [10]. Antioxidant eggs are produced from the laying hens fed with AO ingredients. The AO chicken feed from the UMM Farm Business Unit is added by coconut oil cake. Such innovative product is expected to have more profit value so that the producers have powerful and competitive resources in joining a new market place [11], since nowadays, consumers' behavior has improved in responding to environmentally friendly products [12], [13], and follow the procedure of food safety [14].

Willingness to Pay (WTP) is the customer's willingness to pay for a product that has been added different value from the conventional one [15], including green packaging [13] and organic food. Four previous studies have examined consumers' response and acceptance of differentiated chicken eggs (organic, containing antioxidants or labeled). In the brand image aspect, consumers' perceptions of quality and marketing communication strengthen the marketing of the branded eggs. Further, the AO eggs have also been examined whether they are accepted by consumers with the attributes of aroma, taste, and all their differences from the conventional eggs [8].

A study on consumer behavior is important for the success of marketing AO eggs. Consumer's behavior and purchase intentions on organic food products are influenced by several factors, such as product health state, product availability, and demographic aspect[16]. The market is driven by 
the perceived benefits of organic food rather than the conventionally cultivated food [17].

Some previous studies discussing the attributes of organic foods are easy to find, however, those with the focuses of organic or functional eggs are still rarely found. Consumer's perception of nutritional content, ecology, and price of organic food strongly influences the utilitarian and hedonic manners in purchasing organic food [18]. Organic products in the fresh form are more popular than processed form [19]. The motivation of seeking good food quality which led to proper support for health has affected the purchasing of organic food at low intensities. Selfishness and curiosity about prices become barriers to the purchase of organic food [19]. Selfishness and curiosity about prices become barriers to the purchase of organic food [19]. Based on [20], consumers are segmented based on the actual purchasing ability of the health food and the sustainability of the related products.

Bechtold \& Abdulai [21] found the heterogeneity of preferences between classes of consumer attitudes and functional food. In one class, consumers who are skeptical of functional foods prefer non-functional dairy products, whereas functional food advocates have a negative preference for non-functional dairy products. The psychographic characteristics in the form of health consciousness, food safety concern influence the demand for labeled chicken eggs [22], [23]. Consumer's motivation, health awareness, and concern for food safety havesignificant positive effects on demand for labeled chicken eggs. Meanwhile, factors that boost the negative effect included high egg prices and consumer's low income. Health awareness has a greater influence than concern for food safety.

International literature discussing the WTP analysis on consumers of organic food products, functional or healthier food [15], [21], [24]; [25] and specifically on organic eggs [26] were easily found. The WTP for organic eggs increased due to negative information about previous events of chicken eggs contaminated with Salmonella bacteria in the USA in 2010 [26]. Consumers havea higher awareness of the environment, where the norm and WTP are the strong predictors of buying behavior [25].

Research on labeled eggs was found in Indonesia, observing the effect of psychographic characteristics on demand for labeled chicken eggs in Yogyakarta [23]. The study did not specifically discuss eggs with antioxidant content and did not comprehensively analyze consumers' WTP. Various previous studies on eggs have not analyzed the consumer's perspective. The WTP approach is very important for analyzing the market of differentiated products [21], [24]. The limited reference about purchasing antioxidant eggs supports the importance of this study, intending to analyze consumer's assessment, purchasing behavior, and willingness to pay the AO chicken egg.

\section{Materials and Methods}

The study was conducted on October-December 2019 in Malang Regency, at the closest location to the UMM Farm Business Unit to ensure they sell AO eggs. Primary data were obtained from interviews with customers who consumed the AO chicken eggs and conventionally cultivated chicken egg. The AO chicken egg respondents were the customers who purchased AO chicken eggs and have had prior experience of consuming them, for the benefit of themselves and their families. They were interviewed in the selling place of antioxidant eggs. The three closest grocery stores were chosen because they sell the antioxidant eggs produced by the UMM Farm. They were located in the area of Tegalgondo Village, Karangploso District. Their customers knew the information about the antioxidant eggs eventhough without labels.At the stores, customer sample was determined by purposive sampling. Respondents were customers who were met at the groceries and they bought the antioxidant eggs for at least the second time.The conventional egg customers were determined from the same area by accidental or convenience sampling [27]. The intention was they also obtained information about the presence of antioxidant eggs. The number of respondents in each sample group was sixty (60) people, so the total number of respondents is 120 people.

The data included the customers' assessment on the AO and the conventional chicken eggs, the egg prices at the transaction time, as well as the willingness to pay the labeled AO eggs. The indicators assessed for the AO and conventional eggs were: nutritional content; health benefits; self-health motivation; health impact of consuming the eggs; and the information about antioxidant eggs. The data were analyzed using a 
quantitative descriptive design and a independentsamples t-test.

\section{Results and Discussion}

\section{Customer's description}

The level of customers' income was needed to get an overview of their purchasing ability. Table 1 shows that the distribution of consumer income ranges from one to eleven million rupiahs per month. Most consumers have an average income of 2.5 to 5.0 million rupiahs per month, both for the consumers of $\mathrm{AO}$ and conventional eggs. The distribution of consumer income shows that they came from the lower up to middle class. The purchasing power of this consumer class is sufficient to buy chicken eggs (AO or conventional) for their daily needs(Ariani et al, 2018). The average expenditure per capita/month for the lower income households was IDR 300,411 or the income range of IDR 1,201,000 IDR 1,500,000 per month for 4-5 family members. Ariani et al [28] found that the participation rate of egg consumption of the low income levels was $62.4 \%$, much higher than those of broilers (17.8\%) and beef $(0.9 \%)$. The interesting fact about the income distribution was that the AO egg consumer's income ranges wider (starting from 1-2.5 until 9.5-11.00 million rupiahs, whereas those of conventional egg consumers were narrower (2.5-3.5 to 9.5-11.00 million rupiahs income). Table 1shows that the lowest consumer income for conventional egg was greater than those of the $\mathrm{AO}$ egg.

Table 1 Customer's Characteristics

\begin{tabular}{|c|c|c|}
\hline $\begin{array}{l}\text { Costumer's income } \\
\text { (million IDR/month) }\end{array}$ & $\begin{array}{ll}\text { AO } & \text { Egg } \\
(\%) & \end{array}$ & $\begin{array}{l}\text { Conv. Egg } \\
(\%)\end{array}$ \\
\hline $1-2.5$ & 6.67 & 0 \\
\hline $2.5-3.5$ & 33.33 & 33.33 \\
\hline $3.5-5.0$ & 40 & 40 \\
\hline $5.0-6.5$ & 0 & 6.67 \\
\hline $6.5-8.0$ & 16.67 & 16.67 \\
\hline $8.0-9.5$ & 0 & 3.33 \\
\hline $9.5-11.0$ & 3.33 & 0 \\
\hline Total & 100 & 100 \\
\hline $\begin{array}{l}\text { Costumer's } \\
\text { (years old) }\end{array}$ & & \\
\hline $20-29$ & 33.3 & 33.3 \\
\hline $30-39$ & 23.3 & 20 \\
\hline $40-49$ & 33.3 & 26.7 \\
\hline 50 and more & 10 & 20 \\
\hline Total & 100 & 100 \\
\hline
\end{tabular}

Source: primary data, 2019

\section{Customer Assessment on Eggs}

The AO chicken egg was a new product initiation developed by the UMM Farm Bussiness Unit. The antioxidant eggs have been marketed without brands through a conventional distribution. Even though it was marketed without any brand, there are already many loyal customers $(90 \%$ of respondents) who give positive evaluations of the AO eggs. Table 2 shows the percentage of customers at each assessment score on the AO and conventional eggs. The average score was mention in Figure 1, it indicates the comparison of the consumers' assessment scores for the AO and conventional eggs.

Table 2 Customer's Assessment of eggs

\begin{tabular}{|c|c|c|c|c|c|c|c|c|c|c|}
\hline \multirow[b]{2}{*}{ Score } & \multicolumn{5}{|c|}{$\begin{array}{l}\text { AO Egg } \\
\text { customer (\%) }\end{array}$} & \multicolumn{5}{|c|}{$\begin{array}{l}\text { Conv. Egg } \\
\text { Customer (\%) }\end{array}$} \\
\hline & 1 & 2 & 3 & 4 & 5 & 1 & 2 & 3 & 4 & 5 \\
\hline Nutriti & 0 & 0 & 6. & 3 & 6 & 0 & 3. & 1 & 4 & 4 \\
\hline $\begin{array}{l}\text { onal } \\
\text { conten } \\
\text { t }\end{array}$ & & & 7 & 0 & $\begin{array}{l}3 . \\
3\end{array}$ & & 3 & 0 & $\begin{array}{l}6 . \\
7\end{array}$ & 0 \\
\hline Health & 0 & 3 & 2 & 3 & 4 & 0 & 3. & 6. & 4 & 4 \\
\hline $\begin{array}{l}\text { benefi } \\
t\end{array}$ & & 3 & $\begin{array}{l}3 . \\
3\end{array}$ & 0 & $\begin{array}{l}3 . \\
3\end{array}$ & & 3 & 7 & $\begin{array}{l}3 . \\
3\end{array}$ & $\begin{array}{l}6 . \\
7\end{array}$ \\
\hline $\begin{array}{l}\text { Self- } \\
\text { health }\end{array}$ & 0 & 6 & $\begin{array}{l}2 \\
3\end{array}$ & $\begin{array}{l}5 \\
6\end{array}$ & $\begin{array}{l}1 \\
5\end{array}$ & 0 & $\begin{array}{l}6 . \\
7\end{array}$ & $\begin{array}{l}2 \\
3\end{array}$ & 3 & $\begin{array}{l}3 \\
3\end{array}$ \\
\hline $\begin{array}{l}\text { motiv } \\
\text { ation }\end{array}$ & & 7 & 3 & 7 & 3 & & & 3 & 7 & 3 \\
\hline $\begin{array}{l}\text { Health } \\
\text { impac }\end{array}$ & 0 & 3 & $\begin{array}{l}6 . \\
7\end{array}$ & $\begin{array}{l}4 \\
0\end{array}$ & $\begin{array}{l}5 \\
0\end{array}$ & 0 & $\begin{array}{l}1 \\
3 .\end{array}$ & $\begin{array}{l}2 \\
6 .\end{array}$ & $\begin{array}{l}5 \\
3 .\end{array}$ & $\begin{array}{l}6 . \\
7\end{array}$ \\
\hline $\mathrm{t}$ & & 3 & & & & & 3 & 7 & 3 & \\
\hline $\mathrm{AO}$ & 0 & 3 & 2 & 3 & 3 & 3 & 1 & 2 & 5 & 1 \\
\hline egg & & . & 3. & 6. & 6. & & 0 & 3. & 0 & 3. \\
\hline $\begin{array}{l}\text { infor } \\
\text { matio } \\
n\end{array}$ & & 3 & 3 & 7 & 7 & 3 & & 3 & & 3 \\
\hline
\end{tabular}

Source: primary data, 2019

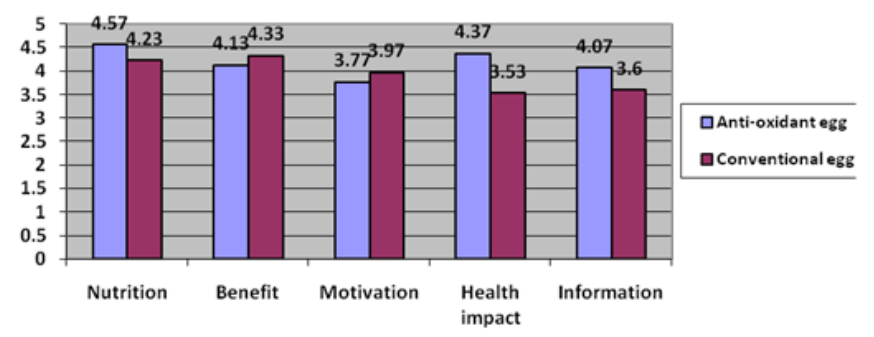

Figure 1 Consumer assessment on eggs 
Figure 1 shows that three out of five AO egg indicators were assessed better than the conventional eggs. Whereas the two indicators of AO egg had lower scores than the conventional eggs. All indicators were assessed by customer using the Likert scale, ranging from one (strongly disagree) up to five (strongly agree).

The nutrient content of the AO eggs hada score of 4.57 (strongly agree), while the conventional eggs received 4.23 (agree). It means that customers assessed the nutritional content of the AO chicken eggsbetter and healthier than conventional chicken eggs. Even though they did not do or read any laboratory test results, their knowledge possessed from various reference sources (internet, social media) led them to believe that the nutritional content of AO eggs was better than the conventional ones. As many as $75 \%$ respondents knew such information from the internet and social media (Instagram, WhatsApp, Facebook), as mentioned in Table 3. The results of this study support the assertion of [29], suggesting that there was an effect of a food safety concern on demand for labeled chicken eggs. Conventional egg customers separately provided an assessment on egg nutrient content, without comparing with AO eggs. The basis of their assessment was their knowledge about eggs as a source of animal protein.

Table 3 Respondents distribution based on source of information

\begin{tabular}{llll}
\hline $\begin{array}{l}\text { Source of AO egg } \\
\text { information }\end{array}$ & $\begin{array}{l}\text { AO Egg } \\
(\%)\end{array}$ & $\begin{array}{l}\text { Conv. Egg } \\
(\%)\end{array}$ \\
\hline $\begin{array}{l}\text { Social media: Instagram } \\
\text { Social }\end{array} \quad$ media: & 20.3 & 10 \\
WhatsApp & & 6.7 \\
$\begin{array}{l}\text { Social media: Facebook } \\
\text { Internet (exeptSocmed) }\end{array}$ & 5 & 0 \\
\& verbal & 21.7 & 18.3 \\
Verbal information & 25 & 30 \\
No information & 0 & 35 \\
\hline Total & $\mathbf{1 0 0}$ & $\mathbf{1 0 0}$ \\
\hline Source: primary data & & \\
\hline
\end{tabular}

Source: primary data, 2019

The health benefits of the AO eggs reached 4.13, means that on average customers agreed with the health benefit of the AO eggs, some of them strongly agreed (score 5). Meanwhile, the counterpart (conventional egg) possessed 4.33, means that on average customers also agreed with the health benefit, however, customers who had score 5 were more (Table 2). This result indicated that the AO eggs customers did not have significantly better knowledge about the health benefits of eggs compared to the conventional egg customers. A significant difference could be seen if the average score was on the different Likert scale categories ( 3 and 4; or 4 and 5). There were only a few customers knew about the specific benefits of AO eggs. This study found that the AO egg customers had not have a better knowledge about the health benefits of AO eggs. This study result differs from the findings of [18], asserting that customers' perceptions of the nutritional content of organic food have a strong influence on hedonic attitudes in purchasing organic food.

Self-motivation in consuming the AO eggs scored 3.77, and the conventional eggs had 3.97. Health motivation in consuming he AO eggs was not higher than the motivation of conventional egg consumers. This finding was different from [29] who mention that health awareness is crucial in consuming any labeled chicken eggs. Although the AO egg customers have confidence in the nutrient content of AO eggs, it does not mean that health motivation encourages them to consume AO eggs. Another consideration suggesting that eggs contain quite high cholesterol has successfully limited adult consumers to consume more eggs. Consumer's age more than 40 years are $43 \%$ on the AO eggs, and $63 \%$ on the conventional egg (Table 1). Purchasing both types, the AO and conventional eggs were preferred for a household whose members were diverse from children until adolescents.

The AO eggs were assessed as having an impact on health with an average score of 4.37 , while the average score on conventional eggs was 3.53. In this indicator, the assessment of the AO eggs was higher than the counterpart. The score difference on this indicator was the biggest compared to the other indicators. Fiveteen respondents $(25 \%$ of AO egg customers) explained their family's experience in consuming the AO eggs. Six respondents have egg-allergic children, if they consume eggs they fell itchy and hives on the skin. However, when they consume the AO eggs, the itchy and hive feeling did not occur. Therefore, these customers become the loyal customers for the AO eggs from the UMM Farm Unit, they buy the AO egg frequently (et least twice a month) for their family's consumption. 
This findings supported the previous studies thatenriched eggs was considered better than conventional eggs [15], [22].

Most customers received the information about the AO chicken eggs from mouth to mouth testimonies or from social media (WhatsApp, Facebook, Instagram) with a score of 4.07, and conventional egg customers' score was 3.60. Hence, even though the consumed AO eggs have not been labeled, customers have already heard and known from spoken and oral resources, especially from the egg retailers, that the eggs sold in the UMM Farm Unit are healthy because they contain antioxidants. Information from the social media was recognized by 32 respondents $(53.3 \%)$ had encouraged the purchase of AO eggs, while verbal information was recognized by 15 respondents $(25 \%)$, and the rest $13(21.7 \%)$ was a combination between internet and verbal information (Table 3).

\section{The Egg Purchasing Behavior}

The research results on the purchasing behavior included the aspects of purchasing volume when the interview done, intensity (per week and month), volume per month, and consumer preference. Four quantity indicators asserted that the purchasing value of the AO eggs was still lower than the conventional eggs. On the opposite, the indicator of consumer preference showed a higher percentage on the AO egg (Table 4).

Table 4. Purchasing behavior

\begin{tabular}{lll}
\hline Purchasing description & AO egg & $\begin{array}{l}\text { Conv. } \\
\text { Egg }\end{array}$ \\
\hline $\begin{array}{l}\text { Purchasing volume, once } \\
\text { (Kg) }\end{array}$ & 1.33 & 1.40 \\
Intensity (per week) & 1.17 & 1.37 \\
Intensity (per month) & 4.68 & 5.48 \\
Volume (Kg/month) & 3.73 & 4.07 \\
\hline
\end{tabular}

Source: primary data, 2019

The low purchase of the AO eggs was due to three reasons. First, some consumers still on trial mode for the AO eggs (1 Kg, once a month), so the purchase volume was still low. Second, there was no label or brand, hence the consumers have not obtained certainty about product quality assurance or it can be said as a trust factor. As it was mentioned earlier that consumers bought AO eggs because of the verbal information and social media. Third, the availability of the AO egg supply was still limited to the groceries around the UMM campus, so the outreach for the distanced customers was still very low.

\section{Willingness to Pay (WTP) for the AO eggs}

In the introduction of new products (AO eggs), a price assessment needs to be done to determine the ability of customers to pay for these products. As many as $80 \%$ of respondents agreed if the antioxidant eggs are packaged and labeled. The AO egg products should be labeled so that customers get clear information about the added treatment and advantages compared to that of the conventional egg. The AO eggs produced by the UMM Farm Unit have not been packaged and given a special label, as in marketing principle, the product packaging and labeling can increase the price. Figure 2 portrays the comparison of average prices between the conventional eggs, the non-labeled AO eggs, and the labeled AO eggs.

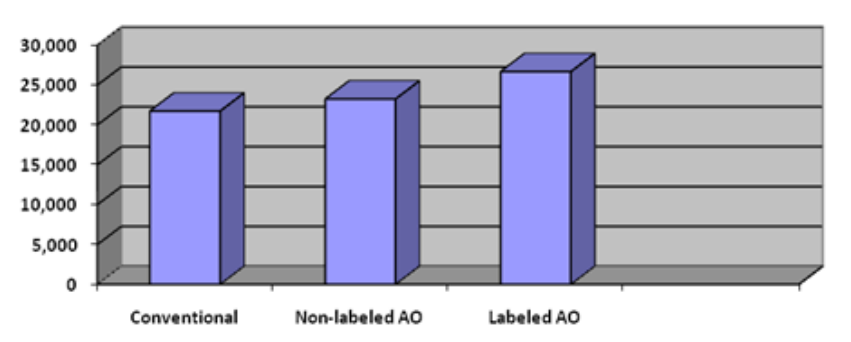

Figure 2 Average Egg Price $(\mathrm{Rp} / \mathrm{Kg})$

The price comparison among the conventional eggs non labeled AO eggs and labeled AO eggs is presented in Figure 2. The average price of non labeled AO eggs was Rp.23,250 per Kg during the time of the study (October-December 2019), while the average price of the conventional eggs was Rp. 21,733. This means that the price of nonlabeled AO eggs was $7 \%$ higher than that of the conventional eggs, although the AO eggs are currently being marketed without labels. The higher set price was set since the Farm Unit of UMM has received "customer trust" based on the merchant's information. They stated that the eggs sold from the farm are healthier. Customer's trust could be known from the re-purchase of AO eggs. If the AO eggs were well packaged and labeled, the average price that customers would be willing to pay was Rp.26,683. With this price, the AO eggs can get a premium price that is $21 \%$ more expensive. Of course, this premium price will be 
achieved if the AO eggs are packaged with elegant package and brand, labeled antioxidant, and included with the expiry date information.

Table 5. The t-test Results

\begin{tabular}{llcl}
\hline Description & Mean t & Sig \\
\hline Pair 1 & $\begin{array}{l}\text { No- } \\
\text { labelAO\&Conventional }\end{array}$ & $1,516.76 .698$ & .00 \\
Pair 2 & $\begin{array}{l}\text { LabelAO \& } \\
\text { labelAO }\end{array}$ & No-3,433.35.806 & .00 \\
\hline
\end{tabular}

Source: analyzed primary data (2019)

From the study, it is strongly encouraged that the UMM Farm Business Unit should pack and label the AO eggs to expand the market. Packaging and labeling will improve customer's intention, motivation, and trust in the authenticity and quality of AO eggs, which lead to the Willingness to Pay (WTP). The primary data showed that the average customer's WTP after labeling and packaging was greater than the existing price of the non-labeled AO eggs. The price difference between non-labeled $\mathrm{AO}$ eggs and conventional eggs was up to Rp1,516/kg. If the AO eggs are labeled, customers are willing to pay as much as IDR $3,433 / \mathrm{kg}$ higher thanthe non-labeled AO eggs.

The t-test results showed that there was a significant difference between the price of the non-labeled AO eggs and conventional egg prices (Table 5). Likewise, the difference between the price of the labeled AO and non-labeled AO eggs was significant. It means that the price of the labeled AO eggs was significantly different from those of the conventional egg. Customers are willing to pay the labeled AO eggsmore expensive. The results of this study support [9], suggesting that consumers who have special health conditions (egg allergy) are more enthusiastic in purchasing organic food because it is healthier. In this research, there were three customers who had experience of egg allergic, it was not occured when they consume the AO egg. Customer's enthusiasm is shown by the WTP which is more expensive of the no-label AO eggs. In the aspect of the AO eggs marketing, packaging and labelling will make it easier and more convenient for the sellers and buyers in a modern retail platform. In new markets with premium prices, producers can obtain higher profits, as stated by [11]. The study results are also in line with [21] who found that consumers who support functional food have positive preferences with functional milk. These results are also supported by several previous studies on environmentally friendly products [12], and safe food [14]. The study result of the AO eggs WTP's rule supports [26]. It is clear that the organic WTP egg increases, and [13], [25] who found that consumers who care of the environment had a higher WTP for the green products.

\section{Conclusions}

Customers have assessed that the eggs with enriched AO have better nutritional content and healthier impact on the human body compared to the conventional ones. Further, customers' purchasing behavior indicated that the purchase of the AO eggs was still lower than the conventional eggs, even though the taste of the delicacy level of the AO eggs showed a significantly higher percentage. From the study, it was also concluded that most customers were willing to pay more expensive for the AO eggs. The price of the nonlabeled AO eggs was 7\% higher than conventional eggs. If the AO eggs are labeled, they will get a premium price of $21 \%$ more than conventional eggs. The results suggested the producers do packaging and labeling of the AO eggs to expand the market. Moreover, it needs to test various packaging designs based on customer preferences and determine a more practical strategy to market the labeled AO eggs products.

\section{Acknowledgments}

This paper was supported by the Block-Grant Fund from the Faculty of Agriculture and Animal Science, University of Muhammadiyah Malang. The writers send the biggest gratitude for the Faculty and UMM for the opportunity and support.

\section{References}

[1] M. J. Islam, M. A. Sayeed, and S. Akhtar, "Consumers profile analysis towards chicken, beef, mutton, fish and egg consumption in Bangladesh," Br. Food J., vol. 130, no. 12, pp. 2818-2831, 2018.

[2] N. Fridayanti, S. Marwanti, and E. Antriyandarti, "Analisis Permintaan Telur Ayam Di Kabupaten Magetan (The Demand Analysis of Chicken Eggs in Magetan Regency)," Agriecobis J. Agric. Socioecon. Bus., vol. 1, no. 2, p. 1, 2018. 
[3] F. Perdana and H. Hardinsyah, "Analisis Jenis, Jumlah, Dan Mutu Gizi Konsumsi Sarapan Anak Indonesia," J. Gizi dan Pangan, vol. 8, no. 1, pp. 39-46, 2013.

[4] A. M. Lestari, A. Hudoyo, and E. Kasymir, "Proyeksi Produksi dan Konsumsi Telur Ayam Ras di Provinsi Lampung," J. Ilmu-Ilmu Agribisnis, vol. 3, no. 3, pp. 287-293, 2015.

[5] G. Minelli, F. Sirri, E. Folegatti, A. Meluzzi, and A. Franchini, "Egg quality traits of laying hens reared in organic and conventional systems," Ital. J. Anim. Sci., vol. 6, no. 1, pp. 728-730, 2016.

[6] E. M. Lengkong, J. R. Leke, L. Tangkau, and S. Sane, "Substitusi Sebagian Ransum dengan Tepung Tomat Merah (Solanum lycopersicum 1 ) Terhadap Penampilan Poduksi Ayam Ras Petelur," J. Zootek, vol. 35 , no. 2 , pp. 247-257, 2015.

[7] P. Panja, "The effects of dietary mulberry leaves (Morus alba L.) on chicken performance, carcass, egg quality and cholesterol content of meat and egg," Walailak J. Sci. Technol., vol. 10, no. 2, pp. 121-129, 2013.

[8] Z. Hayat, G. Cherian, T. N. Pasha, F. M. Khattak, and M. A. Jabbar, Sensory evaluation and consumer acceptance of eggs from hens fed flax seed and 2 different antioxidants, vol. 89. 2010, pp. 2293-2298.

[9] V. A. Nasir and F. Karakaya, "Consumer segments in organic foods market," J. Consum. Mark., vol. 31, no. 4, pp. 263277, 2014.

[10] A. Krystallis and G. Chryssohoidis, 'Consumers' willingness to pay for organic food: Factors that affect it and variation per organic product type," $\mathrm{Br}$. Food J., vol. 107, no. 5, pp. 320-342, 2005.

[11] M. Milenkova, "The impact of product innovation attributes on brand equity," 2015.

[12] H. M. Gonçalves, T. F. Lourenço, and G. M. Silva, "Green buying behavior and the theory of consumption values: A fuzzy-set approach,” J. Bus. Res., vol. 69, no. 4, pp. 1484-1491, 2016.

[13] R. Relawati, B. Y. Ariadi, and B. S. A. Purwono, "The Factors Affecting Green Consumer Behavior: Evidence from Malang, East Java, Indonesia," TEST Eng. Manag., vol. 82, no. February, pp. 7560 7570, 2020.

[14] H. H. Wang, X. Zhang, D. L. Ortega, and N. J. O. Widmar, "Information on food safety, consumer preference and behavior: The case of seafood in the US," Food Control, vol. 33, no. 1, pp. 293-300, 2013.

[15] R. Teuber, I. Dolgopolova, and J. Nordström, "Some like it organic, Some like it purple and some like it ancient: Consumer preferences and WTP for valueadded attributes in whole grain bread," Food Qual. Prefer., vol. 52, pp. 244-254, 2016.

[16] J. Paul, "Consumer behavior and purchase intention for organic food," J. Consum. Mark., vol. 29, no. 6, pp. 412-422, 2012.

[17] M. Massey, A. O'Cass, and P. Otahal, “A meta-analytic study of the factors driving the purchase of organic food," Appetite, vol. 125, no. June, pp. 418-427, 2018.

[18] H.-J. Lee and Z.-S. Yun, "Consumers' perceptions of organic food attributes and cognitive and affective attitudes as determinants of their purchase intentions toward organic food," Food Qual. Prefer., vol. 39, no. January, pp. 259-267, 2015.

[19] J. Van Doom and P. J. Verhoef, "Drivers of and Barriers to Organic Purchase Behavior," J. Retail., vol. 91, no. 3, pp. 436-450, 2015.

[20] S. Sarti, N. Darnall, and F. Testa, "Market segmentation of consumers based on their actual sustainability and health-related purchases," J. Clean. Prod., vol. 192, no. August, pp. 270-280, 2018.

[21] K. Bechtold and A. Abdulai, "Combining attitudinal statements with choice experiments to analyze preference heterogeneity for functional dairy products," Food Policy, vol. 47, pp. 97106, 2014. 
[22] S. S. Utami, "Pengaruh Karakteristik Psikografis terhadap Permintaan Telur Ayam Berlabel di Kawasan Yogyakarta." Tesis Program Pascasarjana Fakultas Pertanian Universitas Gadjah Mada, Yogyakarta, 2014.

[23] S. S. Utami, J. H. Mulyo, and L. R. Waluyati, "Hubungan Pendapatan Konsumen dan Motivasi Pembelian Telur Ayam Berlabel di Kawasan Yogyakarta," Agroekonomika-Jurnal Sos. Ekon. dan Kebijak. Pertan., vol. 6, no. 1, pp. 97-105, 2017.

[24] A. Zingg and M. Siegrist, "People's willingness to eat meat from animals vaccinated against epidemics," Food Policy, vol. 37, no. 3, pp. 226-231, 2012.

[25] A. K. Moser, 'Consumers' purchasing decisions regarding environmentally friendly products_An empirical analysis of German consumers," J. Retail. Consum. Serv., vol. 31, no. July, pp. 389-397, 2016.

[26] T. Li, J. C. Bernard, Z. A. Johnston, K. D. Messer, and H. M. Kaiser, "Consumer preferences before and after a food safety scare: An experimental analysis of the 2010 egg recall," Food Policy, vol. 66, pp. 25-34, 2017.

[27] A. Bhattacherjee, Social Science Research: Principles, methods, and practices. 2012.

[28] M. Ariani, A. Suryana, S. H. Suhartini, and H. P. Saliem, "Keragaan Konsumsi Pangan Hewani Berdasarkan Wilayah dan Pendapatan di Tingkat Rumah Tangga," Anal. Kebijak. Pertan., vol. 16, no. 2, pp. 147-163, 2018.

[29] S. S. Utami, J. H. Mulyo, and L. R. Waluyati, "Pengaruh Karakteristik Demografi dan Ekonomi Terhadap Permintaan Telur Ayam Berlabel di Kawasan Yogyakarta," Agro Ekon., vol. 25, no. 2, pp. 144-149, 2014. 